\title{
Instant Corn Rice Product Development
}

\author{
Khoirul Hidayat *, Mohammad Fuad Fauzul Mu'tamar, R Arief Firmansyah, \\ Wahyudi Illahi \\ Agroindustrial Technology, University of Trunojoyo Madura, Indonesia \\ Jl. Raya Telang, Kamal, Kabupaten Bangkalan, Jawa Timur, Indonesia \\ * Corresponding author: irul_ie@yahoo.co.id
}

\section{ARTICLE INFO}

Article history

Received January 23, 2019

Revised March 27, 2019

Accepted April 18, 2019

Available Online August 31, 2019

Keywords

Product development

Corn

QFD

Food

\begin{abstract}
The Madurese consumes corn as the primary source of carbohydrates. However, currently, they are experiencing a shift in consumption from corn to rice. The availability of abundant rice causes it. Moreover, another reason is that the process of processing corn requires a relatively long time. The purpose of this research is to develop instant Madura corn rice. The method used in this research is the Quality Function Deployment (QFD) method. Based on the House of Quality matrix obtained 16 attributes of consumer needs, both in terms of products and packaging. The highest Attributes of the needs of consumers are attributes without preservatives for the product aspect and presenting attributes for the packaging aspect. There are 17 attributes of technical requirements needed to meet the attributes of consumer needs. The highest priority technical requirements are the corn type attribute for the product side and the font-size attribute for the packaging aspect. The results of product comparisons with competitors, Madura corn rice products have advantages in the yellow color. Furthermore, It needs to be improved attributes about the texture a little soft.
\end{abstract}

This is an open-access article under the CC-BY-SA license.

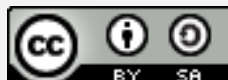

\section{Introduction}

Diversification of food is a government food security policy comprising food and local food technology [1]. Diversification of food is a type of food that is not limited to staple food and other food. It aims to improve the quality of community nutrition in quantity [2]. The development of food diversification is stagnant because of the development of non-rice food technology low. Traditional methods of production and products are considered inferior goods by the public [2]. The Madura people consume corn as the primary carbohydrate source. However, They change in consumption patterns from corn to rice. It was caused Abundant availability of rice. Moreover, another reason is that processing corn takes a long time, $\pm 1-2.5$ hours [3]. 
Some researcher has attempted to diversification food. One of the Efforts to increase the consumption of corn rice is developing instant corn rice products [4]. Instant food products provide benefits in the form of convenience and save cooking time [5]. The development of instant corn rice products is one effort to Diversification of food. It required a response from the market. The development of an instant corn rice product must appropriate the characteristics desired by consumers. It is transformed into product characteristics using the Quality Function Deployment (QFD) method. The QFD method emphasizes consumer needs as a starting point for developing the product [6]. The researcher has used The QFD method for product development in the food field, such as jelly fruit [7], sweets and carrot syrup [8], olive oil extract [9], the mochi cake [10], cookies from sweet potato [11], herbal chili [12], and crispy Peperek fish products [13]. The QFD methods provide benefits in product development by shortening $40 \%$ and reducing the cost by $60 \%$ [14].

Some Research on the development of instant corn rice products has been carried out. The researchers have formulated the best corn rice that is in demand by consumers [4], [15], [16]. Research on the development of corn rice products using the QFD method has never been done before. Therefore, the purpose of this research is to develop instant corn rice products using the QFD method. The overall structure of the study takes the form of six chapters, including In section 1, the background of the problem and the objectives to be explained are outlined. Moreover, section 2 discusses data collection techniques and the stages of designing a product planning matrix. Section 3 outlines the results by describing each step to form a product planning matrix. The final section is the conclusions.

\section{Methods}

\subsection{Data}

The study was conducted three months from September to November 2018 with the research location in Bangkalan, East Java, Indonesia. Data collection techniques used interviews and questionnaires. Interviews were conducted with 100 respondents who had consumed corn rice. Types of interview questions about the types of instant Madura corn rice products involve consumer needs and the level of customer satisfaction. In addition, questions about comparisons with competitor products and technical requirements. The questionnaire aims to get data about the types of instant Madura corn rice products, the level of consumer interest, and the level of consumer satisfaction. Another goal is to find out the level of comparison with competitors' products. This study uses 16 attributes with a 1-5 Likert scale.

\subsection{Product Planning Matrix Design}

The scope of research is limited to the design of the House of Quality (HOQ). The design of $\mathrm{HOQ}$ was used to collected attributes of consumer needs and technical requirements for instant Madura corn rice products. The design of the HOQ matrix consists of the following stages [14], [17], [18], [19], which are illustrated in Fig. 1. 1). The left part of Fig. 1 is the stage of identifying consumer needs to obtain the attributes of consumer needs based on the ranking of the level of consumer interest. 2). Customer competitive assessment. It aims to compare developed products and competing products. 3). Product Requirements. This stage realizes the needs of consumers in the product being developed. 4). Matrix Relation. This section states the relationship between 
product needs and entities. 5). Correlation Matrix. This section describes the relationship between product needs attributes and the effect of each product's needs attributes. The matrix of relationships between attributes of consumer needs and technical requirements is expressed in scale value. It used is scale $9=$ strong relationship, scale $3=$ sufficient relationship, and scale $1=$ weak relationship. While the empty box states the value is zero or there is no relationship.

The under part of the House of Quality contains some information. One part is the HOW MUCHs section. It is used to measure the attributes of product needs expressed in measurable units. The use of measurable targets provides opportunities for further analysis and optimization of product development.

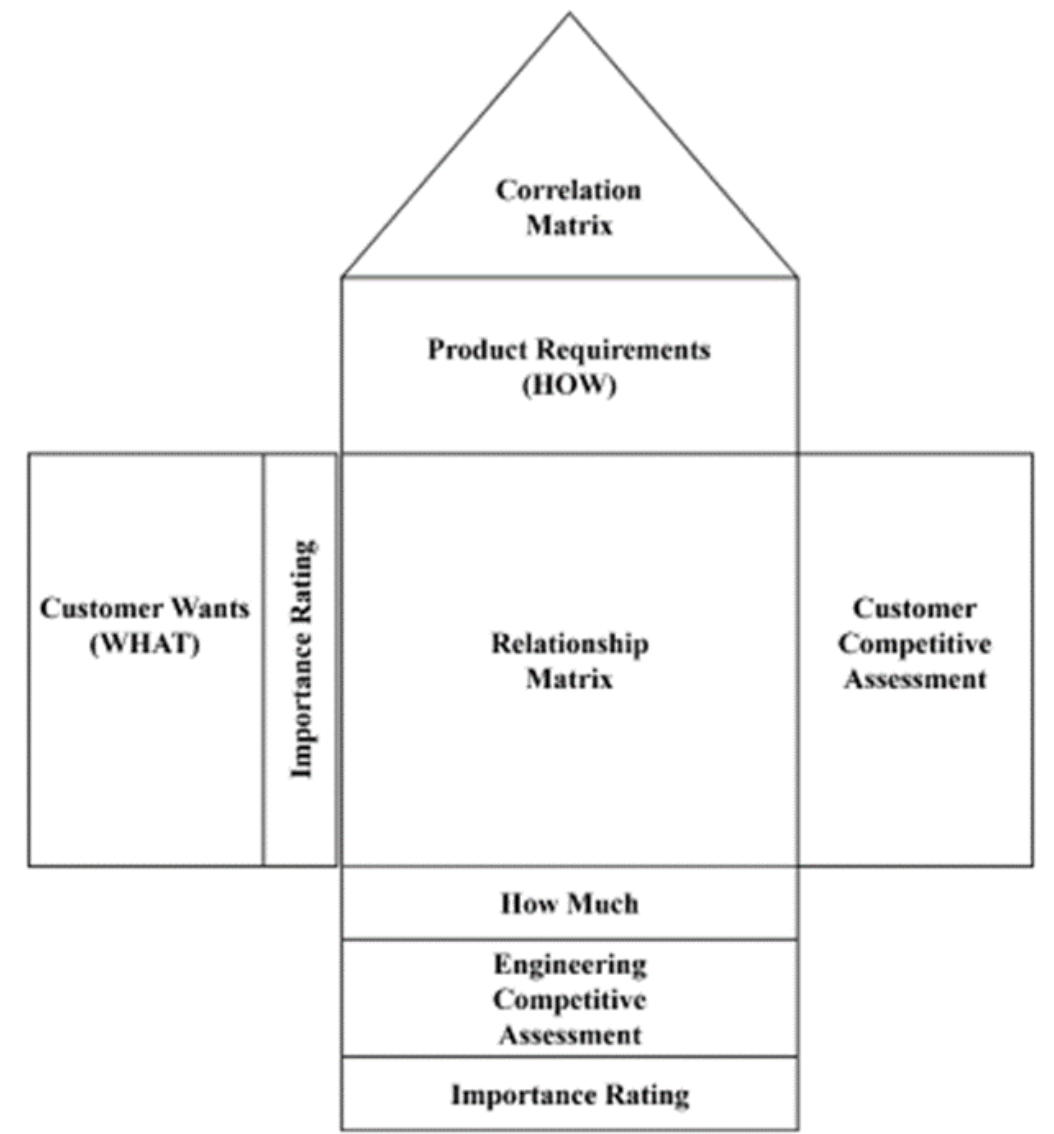

Fig. 1. House of Quality, the first matrix of the QFD method [20]

\section{Results and Discussion}

\subsection{Identification of consumer needs (WHATs)}

The results of interviews with respondents obtained some attributes of consumer needs. Attributes of consumer needs are categorized into two categories. These are based on products and packaging. The attributes of consumer needs are presented in Table 1. Packaging variables in the development of food products are also included in the stages of product development. In the product category, attributes without preservatives, slightly soft, and durable product textures [8] are the most critical consumer needs. The packaging category, presentation suggestions, storage suggestions, and product status [21] include important consumer needs attributes. 
Table 1. Attributes of consumer needs for instant corn rice products

\begin{tabular}{|c|c|c|}
\hline Categorize & Attributes of consumer needs & Rank \\
\hline \multirow{9}{*}{ Product } & The typical aroma of corn & 5 \\
\hline & It tastes good and is typical of corn & 4 \\
\hline & Easy to stored & 8 \\
\hline & Durable & 3 \\
\hline & Yellowness & 9 \\
\hline & Affordable prices & 7 \\
\hline & Without preservatives & 1 \\
\hline & The texture is a little soft when consumed & 2 \\
\hline & Product size is slightly smaller & 6 \\
\hline \multirow{7}{*}{ Packaging } & Packed with plastic & 3 \\
\hline & $\begin{array}{l}\text { The product name, manufacturer name, and } \\
\text { production address }\end{array}$ & 5 \\
\hline & Product Status & 2 \\
\hline & Suggested serving & 1 \\
\hline & Expired date & 4 \\
\hline & Storage suggestion & 2 \\
\hline & Listed product prices & 6 \\
\hline
\end{tabular}

\subsection{Identification of technical requirements (HOWs)}

The technical requirements for instant corn rice were obtained from interviews of two experts. They are experts in the field the process of making corn rice. The results of the technical requirements are presented in Table 2.

Table 2. Technical requirements for instant corn rice products

\begin{tabular}{ll}
\hline Categorized & Technical requirements \\
& Type of corn \\
\hline Color of corn \\
\hline Size of corn rice \\
\hline Long immersion \\
\hline Total of washing \\
\hline Duration of measurement \\
\hline Coconut milk addition \\
\hline The moisture content of corn rice \\
\hline Product weight and shape \\
\hline Packaging tightness \\
\hline Packaging type \\
\hline Packaging strength \\
\hline Packaging image design \\
\hline Packaging form \\
\hline Packaging color \\
\hline Size of letters \\
\hline Volume
\end{tabular}

\subsection{Matrix of relationships between HOWs and WHATs}

In this matrix, we evaluated each attribute. The assessment was obtained from the results of interviews with two expert respondents who also determined the technical 
requirements of the product. The relationship matrix of the HOQ matrix is presented in Fig. 2 and Fig. 3. Based on the relationship matrix, to get instant corn rice products without preservatives, corn rice's moisture content needs to be checked. Decreasing the moisture content of corn rice prevents damage to the product, the development of microbes. It increases the shelf life of the product [22-24]. Technical parameters of immersion and steaming time determine the soft texture of the product. Long immersion reducing the firmness of the corn kernels. Steaming time causes the firmness of corn kernels to decrease. [25-27]. The technical Response in the form of packaging suggestions is the size of the letters or characters used. The packaging suggestion is crucial for the product because it has a positive effect on the willingness to buy for consumers. Therefore, it needs to be carefully designed [28] for the color, size of the text, and image [29].

\subsection{Matrix of relationships between HOWs attribute}

The relationship matrix between the HOWs attributes of the HOQ matrix for the product and packaging aspect is presented in Fig. 2 and Fig. 3. The matrix shows the effect of the relationship between the technical requirements attributes. There are four strong relationships between the technical requirements attributes in terms of products such as (1) attributes of corn type, corn color, and corn rice moisture content; (2) the attributes of corn color, long immersion, and amount of washing; (3) the attributes of corn rice size, corn rice moisture content, and weight and shape of the product; and (4) Attributes of the amount of leaching and moisture content of corn rice. In terms of packaging, there are four strong relationships such as; (1) attributes of packaging tightness, the strength of packaging and the form of packaging; (2) attributes of packaging type and form of packaging; (3) the most vital attributes of the packaging and the shape of the packaging; and (4) The design attributes of packaging images and packaging colors.

\subsection{Consumer competitive assessment}

Consumer competitive assessment aims to determine the comparison of products developed and competitor products. Product comparisons were obtained by distributing questionnaires to 100 respondents. Respondents were given original Madura corn rice and Benchmark instant corn rice. The assessment of the questionnaire used a Likert scale of 1-5. The product comparison results are presented in Table 3. In terms of products, the advantages of Madura instant corn rice are in the yellow color attribute. The attribute that needs to be improved is that the texture attribute is slightly soft. In terms of packaging, all attributes of Madura instant corn rice product packaging are superior to competitors.

\subsection{House of Quality}

Based on the HOQ matrix (Fig. 2 and Fig. 3), the type of corn is a priority the technical requirements for developing Madura instant corn rice. The right type of corn can meet consumer needs such as aroma, taste, easy to store, durable, yellow, and affordable prices. In Madura, there are three types of local varieties [30]. These local varieties have productivity, protein, and fat content better than other varieties [31]. Therefore, these varieties have the potential as raw materials in Madura instant corn rice products. In the aspect of packaging, the priority technical requirements are the 
font-size attribute. It is related to the information displayed on the packaging. Furthermore, Other information such as product names, manufacturers, production addresses, presentation suggestions, expiration dates, storage suggestions, and product prices need to be appropriately designed. Parameters used in good font-sizes are Attracting attention, reading from a certain distance, being read clearly, and attracting interest [32].

Table 3. Comparison of competitive consumer assessment

\begin{tabular}{|c|c|c|c|}
\hline Categorized & Attributes of Consumer needs & $\begin{array}{l}\text { Madura instant } \\
\text { corn rice }\end{array}$ & $\begin{array}{c}\text { Benchmark } \\
\text { instant } \\
\text { corn rice }\end{array}$ \\
\hline \multirow{9}{*}{ Product } & The typical aroma of corn & 3.92 & 3.5 \\
\hline & It tastes good and is typical of corn & 3.81 & 3.72 \\
\hline & Easy to stored & 3.43 & 3.37 \\
\hline & Durable & 3.65 & 3.62 \\
\hline & Yellowness & 4.13 & 2.29 \\
\hline & Affordable prices & 3.55 & 3.32 \\
\hline & Without preservatives & 3.94 & 3.92 \\
\hline & $\begin{array}{l}\text { The texture is a little soft when } \\
\text { consumed }\end{array}$ & 3.44 & 4.28 \\
\hline & Product size is slightly smaller & 3.99 & 2.47 \\
\hline \multirow{7}{*}{ Packaging } & Packed with plastic & 4.45 & 3.8 \\
\hline & $\begin{array}{l}\text { The product name, manufacturer } \\
\text { name, and production address }\end{array}$ & 4.11 & 3.42 \\
\hline & Product Status & 4 & 2.46 \\
\hline & Suggested serving & 4.27 & 4.25 \\
\hline & Expired date & 3.66 & 2.39 \\
\hline & Storage suggestion & 3.28 & 2.4 \\
\hline & Listed product prices & 3.73 & 2.13 \\
\hline
\end{tabular}

The results of the HOQ matrix in the aspect of products, some priorities must be considered to make Madura instant corn rice. In the attributes of consumer needs, there are attributes without preservatives that must be considered to develop Madura instant corn rice products. The technical requirements contained in the attributes of the type of corn, the selection of suitable types of corn produce the right products. Therefore, it attracts consumers to buy Madura corn rice products. In addition to being a benchmark for product quality, raw materials affect production efficiency. Madurese's choice to choose local corn is that the shelf life and yield of Madura corn are higher than that of hybrid corn. [33]. Beta-carotene compounds influence the yellow color in corn. The degradation of beta-carotene is strongly influenced by temperature and duration of heating [4]. The size of corn rice affects the starch gelatinization that occurs in corn. The size of the cross-sectional area of corn rice influences how much water is needed to gelatinize corn [4]. Corn rice water content determines the process of Madura instant corn rice. Water content that is too low causes the development process of corn rice to take a long time, referring to Indonesia National Standard 2886-2015. The weight and shape of instant Madura corn rice desired by consumers in this technical requirement is corn rice using mesh 30 . 


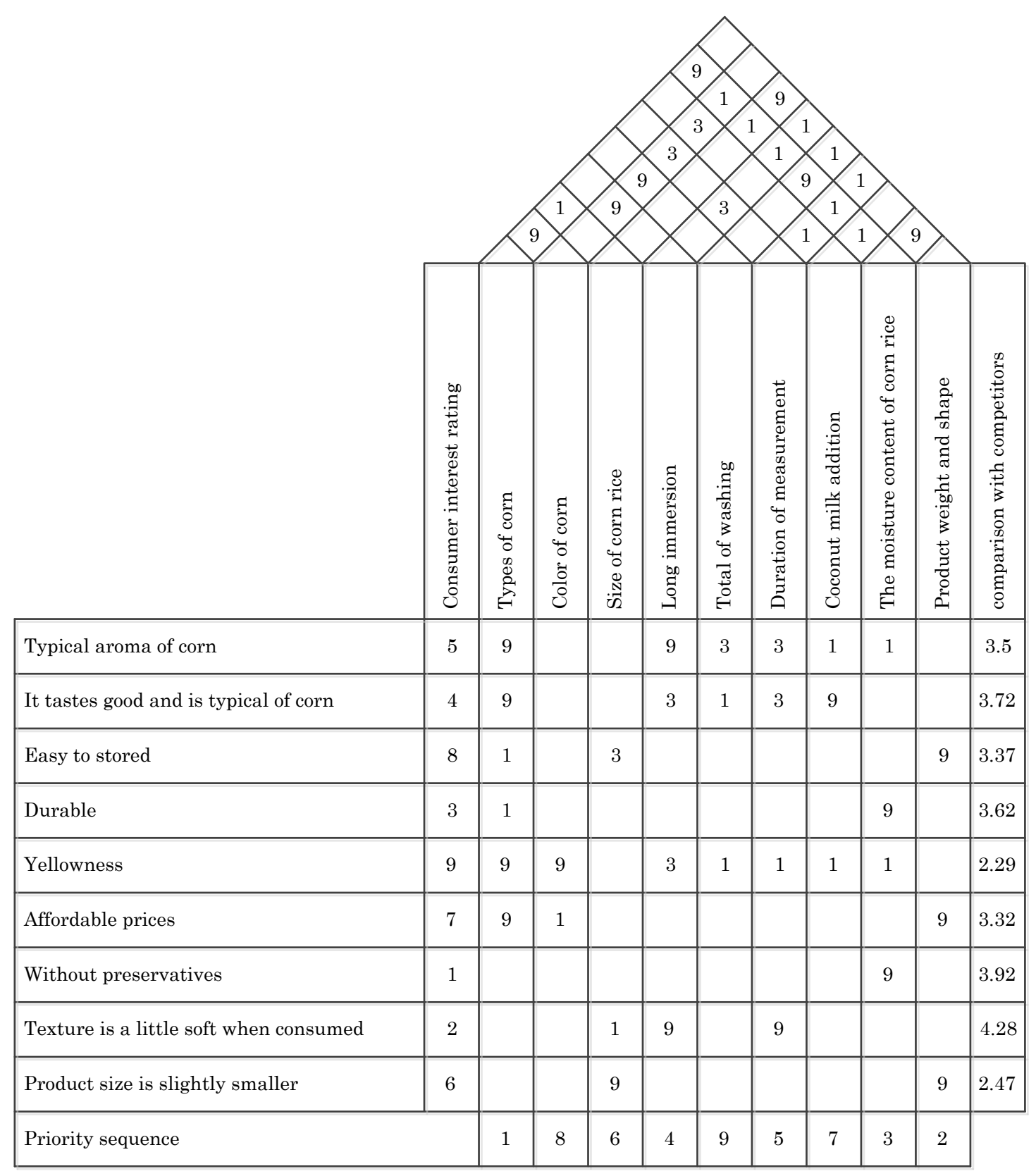

Fig. 2. House of Quality matrix instant Madura corn rice products in terms of products

HOQ corn rice aspect packaging results, the packaging font attribute is the attribute of consumer needs that must be prioritized to develop products. Packaging recommendations must be clear and easy to be read by consumers. The technical requirements in the font-size attribute must be clear and correct to be seen by consumers. These requirements are a priority because the creation of products must have good packaging. The type of corn rice packaging used is the type of polypropylene plastic packaging because of its pressure resistance at low temperatures. [34]. The form of packaging is focused on the form that can describe the volume or content of the product [21]. 


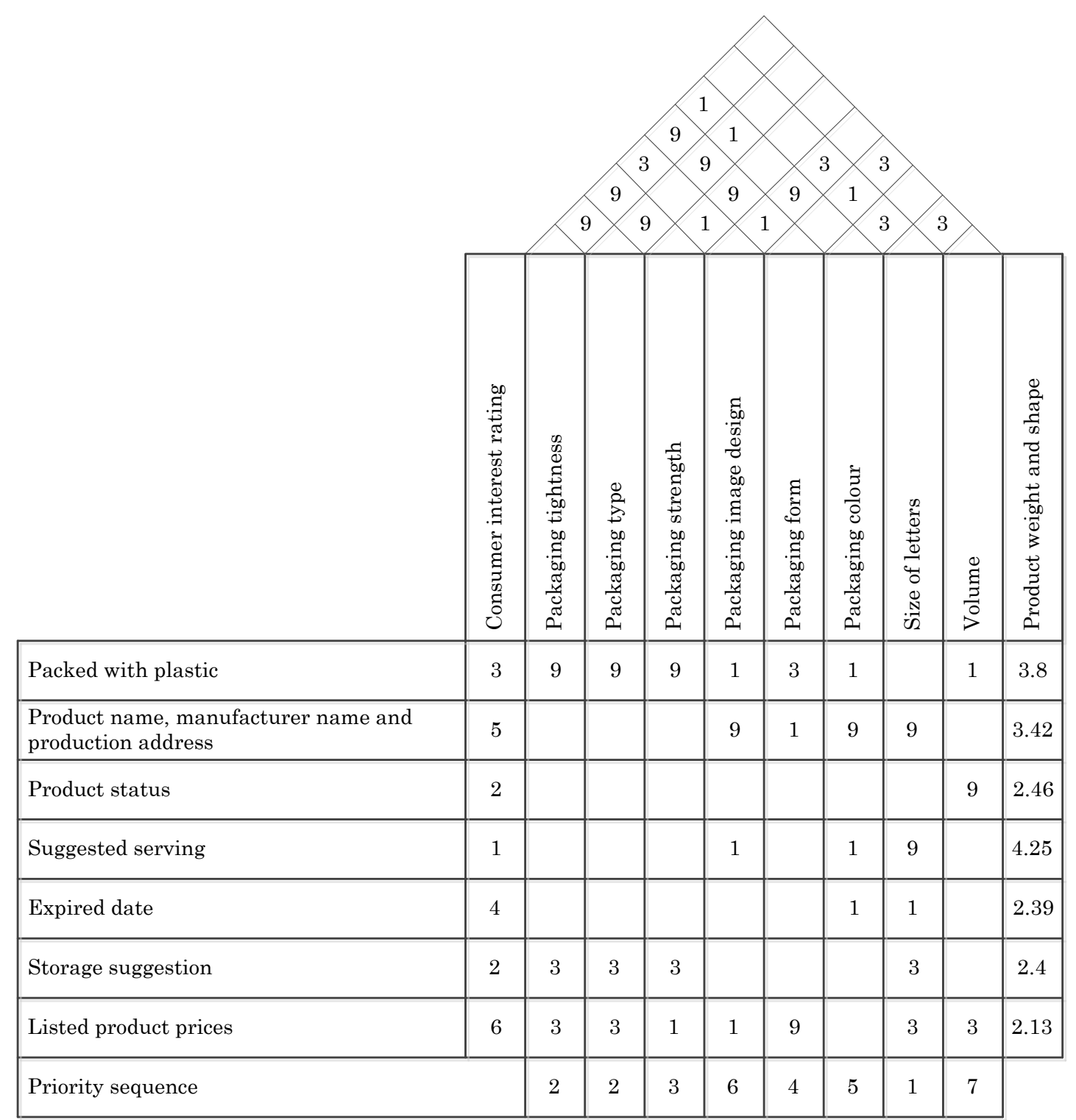

Fig. 3. House of Quality matrix instant Madura corn rice products in terms of packaging

\section{Conclusion}

Based on the compilation of the House of Quality matrix for the development of Madura instant corn rice products, There are 16 attributes of consumer needs in the aspect of products and packaging. For product aspects, Attributes of the needs of consumers who have the highest level of importance are attributes without preservatives. For aspect packaging, attribute packaging has the highest level of importance. There are 17 attributes of technical requirements needed to meet the attributes of consumer needs. The technical requirement attributes that have the highest priority are the corn type attribute for the product side and the font-size attribute for the packaging aspect. The results of comparison of products with competitors, Madura instant corn rice products have advantages in the yellow color attribute. They need to be improved attributes about the texture a little soft so that Madura instant corn rice products can be better. Therefore, the results of Madura 
instant corn rice development are in demand by consumers. The future work given from this study is developing a variety of corn products for other instant food.

\section{References}

[1] T. Bantacut, "Agenda Pembangunan Pertanian dan Ketahanan Pangan 20142019 (Agenda of agricultural Development and Food Security 2014-2019)," Jurnal Pangan; Vol 23, No 3 (2014): Pangando - 10.33964/jp.v23i3.98, 2014. https://jurnalpangan.com/index.php/pangan/article/view/98.

[2] M. Ariani, "Arah, Kendala dan Pentingnya Diversifikasi Konsumsi Pangan di Indonesia," in Forum penelitian Agro Ekonomi, 2016, pp. 99-112. http://dx.doi.org/10.21082/fae.v21n2.2003.99-112.

[3] M. Ariani and E. Pasandaran, "Pola konsumsi dan permintaan jagung untuk pangan," Buku Ekonomi Jagung Indonesia. Badan Peneiitian dan Pengembangan Pertanian. Jakarta, 2005.

[4] Y. N. Azizah, D. R. Affandi, and D. R. A. Muhammad, "Formulasi Dan Kajian Karakteristik Nasi Jagung (Zea Mays L) Instan Yang Disubtitusi Tepung Kacang Hijau (Phaseolus Radiatus)," Jurnal Teknosains Pangan, vol. 3, 2014. https://jurnal.uns.ac.id/teknosains-pangan/article/download/4614/4002.

[5] K. Srinivasan and R. Nirmala, "A Study on Consumer Behavior towards Instant Food Products (With Special References to Kanchipurm Town)," IOSR Journal of Business and Management, vol. 16, pp. 17-21, 2014. www.indianjournals.com/ijor.aspx.

[6] J. Viaene and R. Januszewska, "Quality function deployment in the chocolate industry," Food Quality and Preference, vol. 10, pp. 377-385, 1999. https://doi.org/10.1016/S0950-3293(99)00007-5.

[7] J. d. F. Cardoso, N. Casarotto Filho, and P. A. Cauchick Miguel, "Application of Quality Function Deployment for the development of an organic product," Food Quality and Preference, vol. 40, pp. 180-190, 2015. https://doi.org/10.1016/j.foodqual.2014.09.012.

[8] Y. Ekawati and M. Bazarado, "Designing Food Products Based on Carrots Using the Product Design Phase of Quality Function Deployment," ARPN Journal of Engineering and Applied Science, vol. 11, pp. 3109-16, 2016.

[9] M. Bevilacqua, F. E. Ciarapica, and B. Marchetti, "Development and test of a new fuzzy-QFD approach for characterizing customers rating of extra virgin olive oil," Food Quality and Preference, vol. 24, pp. 75-84, 2012. https://doi.org/10.1016/j.foodqual.2011.09.005.

[10] S. Ariyanti and P. Yuliarty, "Peningkatan Mutu Kulit Kue Mochi Produk Pada Industri Pangan Di Sukabumi," Jurnal Teknik Industri, vol. 5, 2017. https://www.event.lemlit.trisakti.ac.id/tekin/article/viewFile/1519/1309.

[11] D. N. Anjarsari, B. H. Purnomo, and N. Nurhayati, "Perancangan Mutu Cookies Lidah Kucing Ubi Jalar Menggunakan Metode Qfd," Jurnal AgroteknologI; Vol 11 No 02 (2017)DO - 10.19184/j-agt.v11i02.6528, 2018. https://doi.org/10.19184/jagt.v11i02.6528.

[12] M. F. F. Mu'tamar, M. Ulya, and K. Hidayat, "Product development of black Piper retrofractum Vahl tea (black PrV tea)," IOP Conference Series: Earth and Environmental Science, vol. 230, p. 012058, 2019. https://doi.org/10.1088/17551315/230/1/012058.

[13] K. Hidayat, M. A. Prasnowo, N. Nurmawati, V. N. S. Lestari, and D. Abdullah, "Adding Value of Crispy Peperek Product Using Quality Function Deployment 
and Value Added Engineering," Journal of Physics: Conference Series, vol. 1114, p. 012074, 2018. https://doi.org/10.1088/1742-6596/1114/1/012074.

[14] M. Benner, A. R. Linnemann, W. M. F. Jongen, and P. Folstar, "Quality Function Deployment (QFD)—can it be used to develop food products?," Food Quality and Preference, vol. 14, pp. 327-339, 2003. https://doi.org/10.1016/S09503293(02)00129-5.

[15] S. N. Lailiyati, D. R. Affandi, and M. Andriani, "Formulasi Dan Kajian Karakteristik Nasi Jagung (Zea mays L) Instan Dengan Penambahan Tepung Tempe," Jurnal Teknosains Pangan, vol. 3, 2014. https://jurnal.uns.ac.id/teknosains-pangan/article/viewFile/4628/4016.

[16] R. Kumalasari, F. Setyoningrum, and R. E. Ekafitri, "Karakteristik Fisik dan Sifat Fungsional Beras Jagung Instan Akibat Penambahan Jenis Serat dan Lama Pembekuan Physical Characteristics and Functional Properties of Instant Corn Rice due to the Addition of Fiber Type and Duration of Freezing," Jurnal Pangan; Vol 24, No 1 (2015): Pangando - 10.33964/jp.v24i1.41, 2015. http://dx.doi.org/10.33964/jp.v24i1.41.

[17] A. I. A. Costa, M. Dekker, and W. M. F. Jongen, "Quality function deployment in the food industry: a review," Trends in Food Science \& Technology, vol. 11, pp. 306-314, 2000. https://doi.org/10.1016/S0924-2244(01)00002-4.

[18] D. P. Andriani, M. Choiri, and D. Priharseno, "Aplikasi Quality Function Deployment untuk Redesign Kontainer Penyimpanan pada Industri Kemasan Kaleng," Jurnal Teknik Industri, vol. 18, pp. 176-190, 2017. https://doi.org/10.22219/JTIUMM.Vol18.No2.176-190.

[19] I. N. Azizah, R. N. Lestari, and H. H. Purba, "Penerapan Metode Quality Function Deployment dalam Memenuhi Kepuasan Konsumen pada Industri Komponen Otomotif," Jurnal Teknik Industri, vol. 19, pp. 127-136, 2018. https://doi.org/10.22219/JTIUMM.Vol19.No2.127-136.

[20] M. Lukman and W. Wulandari, "Peningkatan Kualitas Produk Cokelat Dengan Integrasi Metode Kano Dan QFD," Jurnal Teknik Industri, vol. 19, pp. 190-204, 2018. https://doi.org/10.22219/JTIUMM.Vol19.No2.190-204.

[21] T. Hanifawati, A. Suryantini, and J. H. Mulyo, "Pengaruh Atribut Kemasan Makanan Dan Karakteristik Konsumen Terhadap Pembelian," Agriekonomika; Vol 6, No 1: April 2017, 2017. http://dx.doi.org/10.21107/agriekonomika.v6i1.1895.

[22] Y. Song, Q. Hu, Y. Wu, F. Pei, B. M. Kimatu, A. Su, et al., "Storage time assessment and shelf-life prediction models for postharvest Agaricus bisporus," $L W T$, vol. 101, pp. 360-365, 2019. https://doi.org/10.1016/j.lwt.2018.11.020.

[23] A. Hadawey, S. Tassou, S. Haddowe, and R. Sundararajan, "Numerical Investigation into the Product's Weight loss and Display Shelf life inside the Serve-over Cabinet," Energy Procedia, vol. 161, pp. 317-324, 2019. https://doi.org/10.1016/j.egypro.2019.02.099.

[24] E. Kamau, C. Mutungi, J. Kinyuru, S. Imathiu, C. Tanga, H. Affognon, et al., "Moisture adsorption properties and shelf-life estimation of dried and pulverised edible house cricket Acheta domesticus (L.) and black soldier fly larvae Hermetia illucens (L.)," Food Research International, vol. 106, pp. 420-427, 2018. https://doi.org/10.1016/j.foodres.2018.01.012.

[25] Y. Yu, F. Pan, H. Ramaswamy, S. Zhu, L. Yu, and Q. Zhang, "Effect of soaking and single/two cycle high pressure treatment on water absorption, color, morphology and cooked texture of brown rice," Journal of food science and technology, vol. 54, pp. 1655-1664, 2017. https://doi.org/10.1007/s13197-017-25984. 
[26] N. Zamindar, M. S. Baghekhandan, A. Nasirpour, and M. Sheikhzeinoddin, "Effect of line, soaking and cooking time on water absorption, texture and splitting of red kidney beans," Journal of food science and technology, vol. 50, pp. 108-114, 2013. https://doi.org/10.1007/s13197-011-0234-2.

[27] S. Sefa-Dedeh, D. Stanley, and P. Voisey, "Effects of soaking time and cooking conditions on texture and microstructure of cowpeas (Vigna unguiculata)," Journal of Food Science, vol. 43, pp. 1832-1838, 1978. https://doi.org/10.1111/j.1365-2621.1978.tb07426.x.

[28] R. Rebollar, I. Lidón, I. Gil, J. Martín, M. J. Fernández, and C. E. Riveres, "The influence the serving suggestion displayed on soft cheese packaging has on consumer expectations and willingness to buy," Food Quality and Preference, vol. 52, pp. 188-194, 2016. https://doi.org/10.1016/j.foodqual.2016.04.015.

[29] K. F. Handoko, "Pengaruh Desain Visual Kemasan, Kualitas Informasi, Dan Kualitas Pelayanan Terhadap Minat Beli Produk Serundeng Mr. Gora secara $\begin{array}{lllll}\text { online," } & \text { Performa, } & \text { vol. }\end{array}$ https://journal.uc.ac.id/index.php/performa/article/view/595.

[30] Z. Arifin and N. Istiqomah, "Pengembangan Jagung Varietas Lokal Sumenep," Pengembangan Jagung Varietas Lokal Sumenep. Dinas Pertanian Tanaman Pangan Kab. Sumenep Bekerjasama dengan Balai Pengkajian Teknologi Pertanian Jawa Timur, 2011.

[31] Z. Arifin, Fatmawati, "Pemurnian Dan Pengembangan Jagung Varietas Manding, Talango Dan Guluk-Guluk Di Kabupaten Sumenep,"Agrointek, vol. 7, pp. 103$112,2012$.

[32] H. Vyas, "Packaging Design Elements and Users Perception: a context in fashion branding and communication," Journal of applied packaging research, vol. 7, p. 5, 2015.

[33] A. Amzeri, "Tinjauan Perkembangan Pertanian Jagung Di Madura Dan Alternatif Pengolahan Menjadi Biomaterial," Rekayasa; Vol 11, No 1: April 2018, 2018. http://dx.doi.org/10.21107/rekayasa.v11i1.4127.

[34] P. Ezzati, I. Ghasemi, M. Karrabi, and H. Azizi, "Rheological behaviour of PP/EPDM blend: the effect of compatibilization," Iran Polym J, vol. 17, pp. 670679, 2008. https://www.sid.ir/en/journal/ViewPaper.aspx?id=115838. 